WPS4213

\title{
Remittances and the real exchange rate
}

\author{
Humberto Lopez, Luis Molina and Maurizio Bussolo*
}

\begin{abstract}
Existing empirical evidence indicates that remittances have a positive impact on a good number of development indicators of recipient countries. Yet, when flows are too large relative to the size of the recipient economies, as those observed in a number of Latin American countries, they may also bring a number of undesired problems. Among those probably the most feared in this context is the possibility of a real exchange rate appreciation and a loss of competitiveness in the tradable sector. This paper explores the empirical evidence regarding the impact of remittances on the real exchange rate. Our findings suggest that indeed remittances appear to lead to a significant real exchange rate appreciation. The paper also explores policy options that may somewhat offset the observed effect.
\end{abstract}

World Bank Policy Research Working Paper 4213, April 2007

The Policy Research Working Paper Series disseminates the findings of work in progress to encourage the exchange of ideas about development issues. An objective of the series is to get the findings out quickly, even if the presentations are less than fully polished. The papers carry the names of the authors and should be cited accordingly. The findings, interpretations, and conclusions expressed in this paper are entirely those of the authors. They do not necessarily represent the view of the World Bank, its Executive Directors, or the countries they represent. Policy Research Working Papers are available online at http://econ.worldbank.org.

\footnotetext{
* World Bank, Bank of Spain and World Bank respectively.
} 


\section{Introduction}

Existing empirical evidence (Fajnzylber and Lopez, 2005) indicates that at the country level higher remittances inflows tend to be associated with lower poverty indicators and higher growth rates. Beyond these typical income dimensions of welfare, remittances seem to reduce output volatility (a measure of risk faced by countries ${ }^{1}$ ), and at least in some countries and for some socio-economic groups lead to improvements in social indicators. Yet, the magnitude of these flows relative to the size of the receiving economies ${ }^{2}$ implies that remittances may also pose an important number of challenges. For while these inflows may ease external financing constraints and therefore hold the potential for higher investment by developing countries, in many circumstances remittances are so large that they can impact macroeconomic stability and more specifically carry a potential for Dutch Disease type of phenomena (see the International Monetary Fund's World Economic Outlook 2005, and the Work Bank's Global Economic Prospects 2006).

Workers' remittances can be viewed as a capital inflow, and therefore the theory on the Dutch Disease phenomenon associated with a surge in inflows (perhaps because of a discovery of new natural resources) can also be applied in this context. In order to isolate the specific channels transmitting remittance shocks through the economy, consider first a small open economy model with no leisure-consumption trade off. In this setup, an increase in remittances is equivalent to a (permanent) increase in incomes of the households.

Assuming that non-tradables are normal goods, this positive income shock results in extra spending on both tradables and non-tradables. Since most Latin American countries are price takers in international markets, a growing demand does not raise prices of tradables. However, since the prices of non-tradables are determined in the domestic economy, they increase due to additional demand, the so-called 'spending effect'. There is also a 'resource movement effect'. The relative price change between tradables and non-tradables makes production in the latter more profitable. Output growth in the non-tradable sectors will push up factor demands, especially for those factors used intensively in these sectors. Increased factor demand by the expanding sectors will be accommodated by factors released from other sectors (the resource movement effect) and, depending on the behavior of total supply of factor, will normally result in higher factor returns in the final equilibrium. The price shift and resource reallocation in favor of non-tradables erode the competitiveness of export oriented sectors and hurt import competing sectors. The final result of this real exchange rate appreciation is normally increased import flows and lower export sales. When the above assumption of no consumption-leisure trade-off in the household utility function is removed the above effects are exacerbated. Without this assumption, an increase in non-labor income, as is the case with remittances, influences household decision to supply labor; namely, individuals can now consume more of both goods and leisure (i.e. the income effect dominates) and thus their labor supply is reduced. In turn, reduced labor supply implies raising wages and this additional pressure on wages intensifies the effects of real exchange rate appreciation described earlier.

\footnotetext{
${ }^{1}$ See Perry, Arias, Lopez, Maloney and Serven (2006) for a discussion of non-monetary dimensions (including risks considerations) of welfare.

${ }^{2}$ It has to be mentioned that there are a number of Latin American countries where remittances are above 10 percent of GDP and there are cases, such as Haiti, where they reach almost 40 percent.
} 
Obviously, the pressure on the real exchange rate will be somewhat mitigated if (i) there are productivity gains, particularly in the non tradable sector, that offset the effects of the increasing demand; (ii) governments implement policies that aim at stimulating labor demand by reducing labor costs; ${ }^{3}$ and (iii) a large share of the remittances is channeled to the external sector via additional imports so that the price effect on non tradable goods is limited. Yet in principle it seems difficult to justify that these effects are enough to mitigate appreciating pressures.

In turn, there are a number of connected macroeconomic effects that can result from a real exchange rate appreciation associated to remittances flows. They include the following:

- Adverse effects on the tradable sector of the economy. Although remittance flows are likely to lead to an expansion of the non tradable sector (as a result of the increase experienced in the domestic demand), both export and import-competing industries (i.e. the tradable sector of the economy) would be adversely affected by the real exchange rate appreciation and the associated loss of international competitiveness. The negative impact of remittances on the tradable sector may be reinforced if they also fuel inflation and higher prices result in higher economy-wide wages. ${ }^{4}$ As mentioned above this effect would further be magnified if remittances also reduce the labor supply. In these circumstances, the non tradable sector may be in the position of passing onto prices some of the wage pressures, but this is likely to be much more difficult for a tradable sector facing international competition which as a result will loose competitiveness.

- Widening of the current account deficit. In principle, it is difficult to justify that an increase in the domestic demand will be passed in full to the non tradable sector. So, to the extent that some of the remittances-induced-consumption is directed towards tradable goods, there will be an increase in the demand for imports. This coupled with the losses of international competitiveness of the domestic firms mentioned in the previous paragraph would likely result in deteriorations of the external position. For example, according to World Bank (2003) the surge in remittances observed in El Salvador during the 1990s was the most likely factor behind the worsening of the country's trade deficit which over the 1990s deteriorated from less than 7 percent of GDP to almost 14 percent of GDP.

- Weaker monetary control, inflationary pressures, and the sectoral allocation of investment. If remittances flows do not leave the country (at least in full) through a widening of the current account, large flows will push up monetary aggregates, potentially derailing inflation targets. Experience also indicates that prices of financial assets and particularly of real estate can rise rapidly following a surge in remittances, something that in turn may introduce significant distortions in the economy and affect the sectoral allocation of investment and lead to overinvestment in some sectors (i.e. real estate).

\footnotetext{
${ }^{3}$ A reduction of payroll (or other direct) taxes (compensated by an increase in indirect taxes) is the most straightforward of such policies; however, one can also think of other polices that increase labor market flexibility and ultimately reduce wage pressure (and support labor demand).

${ }^{4}$ This is a typical result of economic models with labor mobility.
} 
On the whole, the previous discussion highlights a number of problems that policy makers may have to face in the context of a surge in remittances. True, to the extent that these Dutch Disease phenomena are part of the natural adjustment process towards a new equilibrium, they should not be a matter of particular concern for policy makers. Indeed, if we view remittances as a positive shock to the economy, then the real appreciation and related effects experimented by the receiving country would simply be part of the inevitable relative price adjustment process that goes with favorable shocks. Yet if this real appreciation is very dramatic, or the adjustment process towards the new equilibrium is uneven (i.e. not fully consistent with the change in economic fundamentals at each point in time) policy makers may wish to mitigate, to the extent possible, its adverse effects on export industries.

In principle, one could also mention two additional reasons of concern for policy makers that are usually mentioned in the context of surges of capital inflows. One is the potential for a flow reversal over the medium run. This is important because if there is hysteresis in the real sector, a real exchange rate appreciation may wipe out important sectors of the economy that would not reappear even if the currency subsequently depreciates. The other potential concern is a very sudden appreciation that cannot be accommodated and therefore brings a very painful adjustment. However, it must be noted that the documented stability ${ }^{5}$ and counter-cyclicality of remittances would lead one to assume that the probability of short-run reversals or sudden adjustments is quite low, leaving as main reason for concern the magnitude of the real appreciation associated to the remittance inflows.

Against this background, what does the economics literature have to say about the evolution of the exchange rate in countries that have experienced important increases of remittances? The truth is that the existing empirical literature is very limited and less than unanimous. For example, Amuedo-Dorantes and Pozo (2004) rely on cross country econometrics techniques and find that in a sample of 13 Latin American countries ${ }^{6}$ a doubling of workers remittances would lead on average to a real exchange rate overvaluation of about 22 percent. This estimate would be robust to the presence of fixed effects in the data, and to the use of IV estimation techniques to account for reverse causality from the exchange rate to remittances.

However, Rajan and Subramanian (2005), who rely on a cross national dataset of 3-digit industry value added growth data to explore whether remittances have a differential impact depending on the labor intensity of the different industries, find that unlike other types of capital flows (particularly aid flows) remittances do not seem to have a negative impact on external competitiveness. Rajan and Subramanian (2005) argue that this could be the result of remittances being directed to a large extent towards unskilled-labor intensive activities - e.g. goods and services provided by micro-enterprises - and/or tradable sectors such as manufacturing, and thus having limited effects on the prices of skilled labor and other relatively scarce resources.

\footnotetext{
${ }^{5}$ The stability of remittances over time is one of the most important differences between remittances and other types of capital inflows. In fact, as noted by the Word Economic Outlook 2005, non-FDI private capital flows, exports, FDI, and even official aid all show greater volatility than remittances.

${ }^{6}$ The countries in their sample are: Argentina, Belize, Bolivia, Colombia, Dominican Republic, El Salvador, Guatemala, Honduras, Jamaica, Mexico, Nicaragua, Peru, and Trinidad \& Tobago.
} 
This paper addresses these issues and contributes to the existing limited literature along several dimensions. First, it discusses the different channels through which remittances can affect the real exchange rate using a framework where the equilibrium exchange rate is characterized by an external equilibrium similar to those analyzed in asset market models (Mussa, 1984 and Frenkel and Mussa, 1985) and an internal equilibrium based on a productivity differential model as those in Balassa (1964) and Samuelson (1964).

Second, it provides estimates of the impact of remittance flows on the real exchange rate using a large cross national data set rather than information for a limited number of countries. Our approach allows testing whether there are regional differences and more specifically whether Latin America is different in this context. Note that one of the main differences between the work of Amuedo-Dorantes and Pozo (2004) and Rajan and Subramanian (2005) is the coverage of the data. Thus if the impact of remittances on the real exchange rate is different in Latin American than in the rest of the world, then the different findings of Amuedo-Dorantes and Pozo (2004) and Rajan and Subramanian (2005) should not be surprising. In fact, to anticipate some of the results in Section IV, this paper argues that remittances flows appear to affect the real exchange rate at a global level and that Latin American countries do not appear to be an exception. These results are robust to the presence of fixed effects in the data, potential reverse causality from the exchange rate to remittances, and variations in the set of control variables.

Third, the paper also explores the extent to which the estimated appreciation in Latin America is consistent with the change in economic fundamentals implied by the increase in remittances or instead whether it can be attributed to changes in the misalignment component of the real exchange rate (i.e. changes in the underlying real over/undervaluation of the currency). To also anticipate our results on this, we find that the evolution of the Latin American real exchange seems to be driven by a combination of changes in the equilibrium real exchange rate and changes in the degree of misalignment.

Finally, on the basis of its empirical results the paper discusses a number of options for policy makers concerned with the impact that a surge in remittances may have on the external competitiveness of the country. In particular, we discuss the possibility that a revenue-neutral policy of a partial switch from direct to indirect taxation may reduce labor costs and thus (at least to a degree) sterilize the negative labor supply effect as well as the real exchange rate appreciation due to rising remittances - an encouraging outcome for countries under budget constraint pressure. The rest of the paper is organized as follows. In Section II we consider an additional number of theoretical considerations that may explain why remittances may lead to a real exchange rate appreciation and review the evolution of remittances, the real exchange rate, exports and imports for the 8 largest receivers of remittances (as a percentage of GDP) in Latin America. Section III reviews the empirical strategy used to assess the impact of remittances on the real exchange rate. In Section IV, we present the results of estimating two econometric models. One relates changes in the real effective exchange rate to the ratio of remittances to GDP. The second uses as explanatory variable the changes in a measure of real exchange rate overvaluation. The basic idea here is trying to disentangle how much of the observed changes in the real exchange rate are due to changes in the equilibrium exchange rate and hence consistent with the evolution of economic fundamentals. Section V discusses whether one specific policy option (shifting the tax structure from direct towards indirect taxation) can contribute to 
somewhat alleviating the loses in competitiveness that seem to come associated to a surge in remittances. Note that this intervention would aim at expanding the labor supply. Finally Section VI closes with some conclusions and a review of policy options.

\section{Remittances and the real exchange rate}

\section{Theoretical considerations}

Remittances can potentially affect the real exchange rate through three main channels (see the technical annex for a formal discussion). First, remittances may affect the external equilibrium of the economy by raising the net foreign asset position of the country. For example, the theoretical models of Mussa (1984), Frenkel and Mussa (1985), Alberola and Lopez (2001) and Aberola et al. (2002) imply that the external equilibrium of the economy will be reached when any current account imbalance is compensated by a sustainable flow of international capital. In turn, the rate of sustainable capital flows will be a function of the stock of foreign assets and liabilities of the economy, so that changes to the net foreign asset position of the country will lead to changes in the real equilibrium exchange rate.

Given that international remittances are transfers of foreign currency that unlike other types of international flows have no obligation associated, remittances will have a direct impact on the net financial position of the country vis a vis the rest of the world. Note in this regard that the impact of remittances on the stock of net foreign assets differs from the impact of other flows such as loans or foreign direct investment flows. In the case of a loan, there is an associated liability (the repayment) and therefore the contribution to the net foreign asset position of the country is given by the difference between the proceeds and the net present value of the repayment obligations. In this regard, loans will positively affect net foreign assets to the extent that they have a positive grant component. On the other hand, foreign direct investment flows coming into the home country will increase the foreign liabilities and therefore, will lead to a decline of the net foreign asset position.

Second, remittances can also affect the internal equilibrium of the economy understood as the situation where domestic capital and labor are efficiently utilized. If as discussed above, remittances lead to an acceleration in the demand for services, inflation will tend to be higher in these sectors which typically are not tradable (and hence somewhat protected from competition) leading to a real exchange rate appreciation (the traditional Balassa-Samuelson effect). Similarly, market rigidities may result in productivity differentials between sectors.

For example, if remittances raise the reservation wage, then excessive wage pressures in the tradable sector may lead to employment adjustments to maintain competitiveness, whereas in the non-tradable sector employers may admit these pressures because they can pass them onto prices. As a result, remittances can also lead to higher productivity growth and lower inflation in the tradable sector through their potential impact on the reservation wage. One implication of this discussion is that whether remittances are primarily used for household consumption or investment purposes will have a direct impact on the way they affect the real exchange rate, with 
remittances that are predominantly consumption oriented having more of an appreciating impact on the real exchange rate.

A third possibility for remittances to affect the real exchange rate is through their impact on growth (Acosta, Calderon, Fajnzylber, and Lopez, 2007), although in this case the impact on the exchange rate is likely to be uncertain. On the one hand, an acceleration in the growth rate would lower the stock of net foreign assets as a percentage of GDP and hence this would lower the real exchange rate (i.e. growth would have the same impact as an increase in the liabilities of the country). If on the other hand, the net foreign asset position of the country is negative vis $a$ vis the rest of the world, the increase in the rate of growth would lower the liabilities to GDP ratio and hence lead to an appreciation.

Table 1. Remittances and the real exchange rate.

\begin{tabular}{|c|c|c|c|}
\hline & \multirow{2}{*}{$\begin{array}{c}\text { REER 1/ } \\
\text { Growth }\end{array}$} & \multicolumn{2}{|c|}{ Remittances 2/ } \\
\hline & & Initial & Final \\
\hline Argentina & -1.6 & 0.7 & 0.5 \\
\hline Belize * & 32.6 & 3.4 & 1.7 \\
\hline Bolivia & -0.3 & 0.1 & 1.5 \\
\hline Brazil & -5.3 & 0.1 & 0.6 \\
\hline Chile & 0.1 & 0.0 & 0.0 \\
\hline Colombia & 0.5 & 1.1 & 4.0 \\
\hline Costa Rica & 0.3 & 0.2 & 1.8 \\
\hline Dominican Republic & -0.4 & 5.0 & 12.7 \\
\hline Ecuador & 3.0 & 0.5 & 5.7 \\
\hline El Salvador & 3.4 & 7.4 & 16.1 \\
\hline Guatemala & 3.3 & 1.6 & 8.7 \\
\hline Haiti & 3.0 & 2.7 & 41.2 \\
\hline Honduras & 1.1 & 2.1 & 12.5 \\
\hline Jamaica & 1.0 & 4.4 & 17.7 \\
\hline Mexico & 1.8 & 1.2 & 2.4 \\
\hline Nicaragua $* *$ & -1.3 & 0.5 & 10.6 \\
\hline Panama & -1.2 & 0.3 & 0.7 \\
\hline Paraguay & -1.6 & 0.6 & 3.7 \\
\hline Peru & -0.6 & 0.3 & 1.4 \\
\hline Venezuela $* * *$ & -1.5 & 0.1 & 0.2 \\
\hline \multicolumn{4}{|l|}{$1 /$ percent } \\
\hline \multicolumn{4}{|l|}{ 2/ percent og GDP } \\
\hline \multicolumn{4}{|c|}{ Initial Period is 1990 and Final Period is 2003} \\
\hline \multicolumn{4}{|c|}{ * Belize Initial Period=1990, Final Period=2002 } \\
\hline \multicolumn{4}{|c|}{ ** Nicaragua, Initial Period $=1992$, Final Period $=2003$} \\
\hline \multicolumn{4}{|c|}{$* * *$ Venezuela, Initial Period $=1997$, Final Period $=2003$} \\
\hline
\end{tabular}

On the internal front, faster growth would be associated with a real exchange appreciation. Higher growth would lead to higher internal demand and the mechanism described above in the description of the internal adjustments will apply (i.e. the Balassa-Samuelson argument). Thus on the whole, the impact of a growth acceleration could go in either direction or even cancel each other and have no impact. 
How do the data look like?

We now move beyond the theoretical considerations just discussed and focus on the data. Table 1 reports the (annualized) change in the (log) real exchange between 1990 and 2003 for a number of Latin American countries, together with the initial and final levels of remittances (in percent of GDP). The remittances data are those of Aggarwal, Demirguc-Kunt, and Martinez Peria (2005). The real effective exchange rate is from the IMF's International Financial Statistics and it is defined as the relative price of domestic to foreign goods, so that increases imply a real exchange rate appreciation. Table 1 indicates that over 1990 and 2003 the real effective exchange rate appreciated in 11 of the 20 countries under consideration. The countries where it appreciated the most are Belize, Ecuador, El Salvador, Guatemala, and Haiti. Interestingly, Ecuador, El Salvador, Guatemala, and Haiti are among the top receiver countries of remittances of the region (as percentage of GDP). Other countries where the real effective exchange rate appreciated over the period under consideration by at least 1 percent per year on an annual basis are Honduras, Jamaica and Mexico. The first 2 of those are also among the countries of the region with a high remittance to GDP ratio, whereas Mexico is the country with the larger remittances flows of the world.

Figure 1 presents similar information but now restricting the sample to the 8 Latin American countries with the largest remittances to GDP ratio in 2002. Even though we should stress that this figure can only provide evidence of unconditional correlations, it is suggestive of a positive relationship between the evolution of remittances and the real effective exchange rate. In fact in most of the 8 countries in the figure it is possible to observe a real exchange rate appreciation in parallel to an increase in the remittances to GDP ratio. The first apparent exception to this rule would be Nicaragua, where the evolution of the real exchange rate over the early 1990s and 2000s appears to move in the opposite direction to what one could expect. The second exceptions are given by Ecuador and the Dominican Republic, where marked real depreciations followed the crisis of 1999 and 2002, respectively, at a time when remittances were increasing substantially. However, in the case of the Dominican Republic the real exchange rate and the remittances to GDP ratio also moved in parallel before 2002.

Note also that in some of the other countries the observed real exchange rate appreciations have been quite dramatic. For example in Ecuador, El Salvador, Guatemala, and Haiti, over the 1990-2003 period the real exchange rate appreciated by about 40 percent. In the cases of Honduras and Jamaica the recorded appreciation is more modest but it would still be in the 20 percent range.

In Figure 2 we now compare the evolution of the real exchange and the volume of exports of good and services. The figure indicates that the only countries where export volumes have significantly increased over the 1990-2003 period are El Salvador, a country where exports increased from about 19 percent of GDP in 1990 to close to 30 percent in 2003, and Ecuador where exports increased by almost 20 percentage points to close to 55 percent of GDP. In Honduras, and Nicaragua export volumes would have been more or less stable over this period oscillating between 30 and 40 percent of GDP in the case of Honduras and hovering around 25 
percent in the case of Nicaragua (although with a large variance). In the rest of the countries under analysis, we observe declines in export volumes which in some cases have been quite dramatic. For example, in Guatemala and Jamaica export volumes have fallen over the period under analysis by about 10 percentage points of GDP.

As for the evolution of imports, figure 3 indicates that over the 1990-2003 there is only 1 country where the imports to GDP ratio fell (Ecuador). In the other 7 countries under analysis imports increased. True in some countries like Guatemala, Jamaica and Nicaragua only slightly (by less than 10 percentage points of GDP), but in the cases of Honduras and Haiti the increase has been quite marked: 15 percentage points of GDP in Honduras and close to 30 percentage points of GDP in Haiti.

Overall, the previous figures would indicate that in general increases in remittances have been accompanied by real exchange rates appreciations, and these in turn by declines in exports and increases in imports, elements that could be taken as a lose of competitiveness. The next section explores whether the empirical evidence is also supportive of some causality from development on the remittances front to the evolution of the real exchange rate.

\section{Empirical strategy}

\section{Empirical model}

To explore the existence of causal links between the real exchange rate and remittances in the data, we rely on the following regression model:

$$
\Delta q_{i t}=\omega^{\prime} x_{i t}+\beta \Delta R_{i t}+v_{i}+v_{i t}
$$

where $q$ is the $\log$ of the real effective exchange rate, ${ }^{7} \Delta$ is the first difference operator (such that $\Delta q_{t}=q_{t}-q_{t-1}$ ), $R$ is a measure of remittance flows (in the case of this paper the remittances to GDP ratio $^{8}$ ), $x$ represents a set of control variables, which we shall discuss shortly, $v_{i}$ is a country-specific effect, and $v_{i t}$ is an i.i.d. error term. Finally, $i$ and $t$ are a country and a time index respectively. Note that what drives the evolution of the exchange rate in (1) is the evolution of remittances rather than its stock (see the appendix for a discussion). In other words, if stable even high remittance flows will be consistent with a stable reach exchange rate.

Figure 1. Remittances and the real exchange rate

\footnotetext{
${ }^{7}$ Recall that as argued above increases in $q$ correspond to a real exchange rate appreciation.

${ }^{8}$ In this context, it seems more appropriate to work with the remittances to GDP ratio than with for example remittances per capita. The reason is that in principle one would expect that the real exchange rate is more affected when remittances are large relative to the size of the economy than when they are large relative to the population.
} 

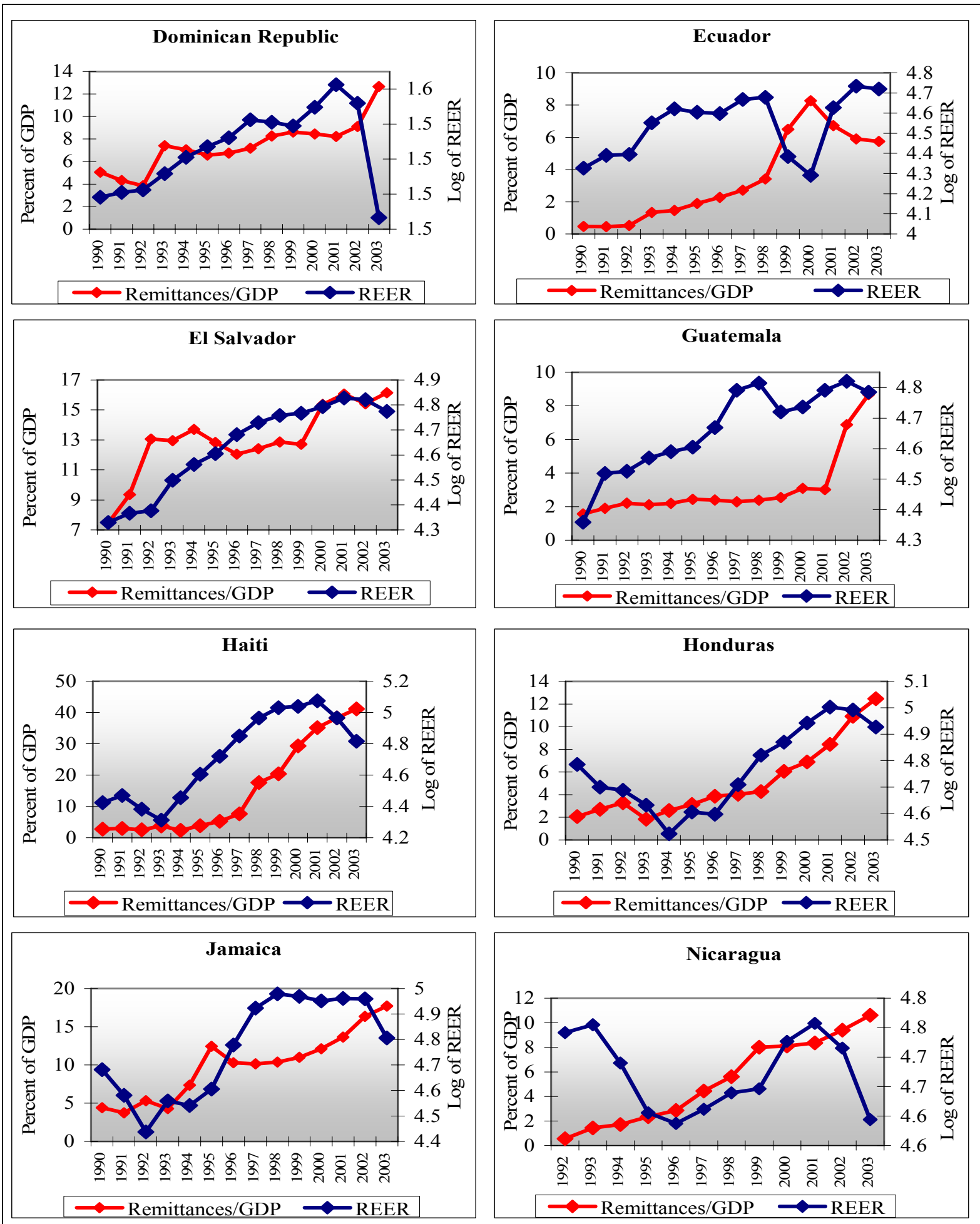

Note: increases in the REER index indicate a real appreciation. Source: Author's calculations. 
Figure 2. Exports and the real exchange rate
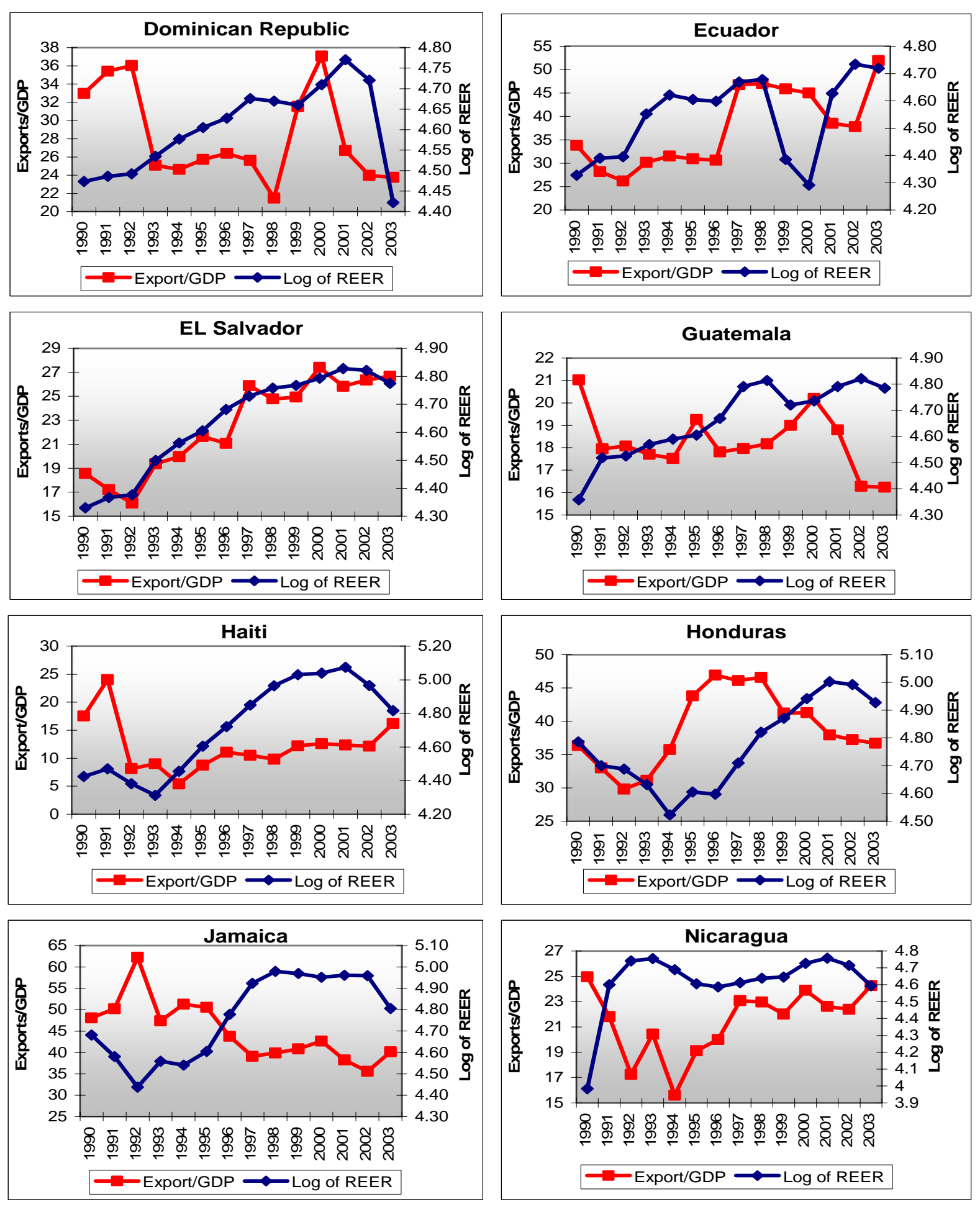

Note: increases in the REER index indicate a real appreciation. Source: Author's calculations. 
Figure 3. Imports and the real exchange rate
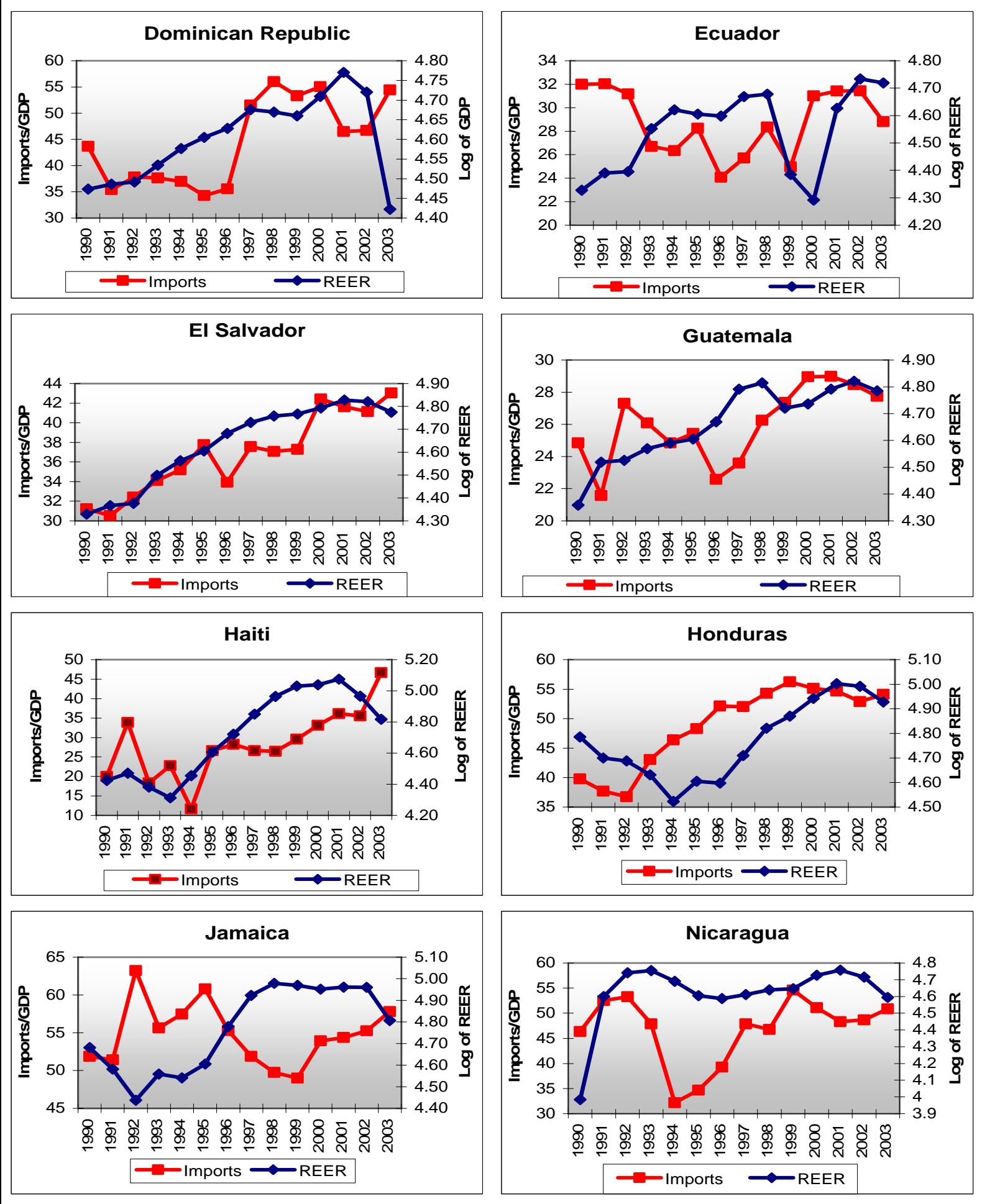

Note: increases in the REER index indicate a real appreciation. Source: Author's calculations. 
Our primary focus is the estimate of $\beta$ in equation (1). If an increase in remittances leads to a real exchange appreciation we should find that $\beta>0$. If, however, remittances have no impact on the real exchange rate then we should find $\beta=0$. Although it is theoretically possible here we do not consider the possibility of $\beta<0$, since this would imply that remittances contribute to real exchange rate depreciation. ${ }^{9}$ (See the technical annex for a discussion.)

The previous model can easily be extended to allow remittances to have a different impact in Latin America and in the rest of the world by simply adding and additional regressor to the specification in equation $(1):^{10}$

$$
\Delta q_{i t}=\omega^{\prime} x_{i t}+\beta_{1} \Delta R_{i t}+\beta_{2} \Delta R_{i t} \times l a c+v_{i}+v_{i t},
$$

where $l a c$ is a dummy variable that takes a value of 1 if the country in question is in Latin America and 0 otherwise.

One additional issue that needs attention is the specific set of control variables that are included in $x$. Here we follow to a large extent the strategy in Amuedo-Dorantes and Pozo (2004) and consider the terms of trade, government expenditure, the world real interest rate, and GDP per capita income. These variables would capture respectively the effects of potential external shocks, fiscal policy differences, changes in external financial conditions, and productivity gains. ${ }^{11}$

Despite the broad similarities between equations (1) and (2) and those estimated by Dorantes and Pozo (2004) there are a number of important differences. First, our results are based on a large cross national dataset rather than on a limited number of countries (in the case of Dorantes and Pozo, 2004, 13 Latin American countries). In fact, if Latin American migration patterns are different from those of other regions, this could also be reflected in a differentiated effect of remittances on the real exchange rate.

Second, we focus on changes in the exchange rate rather than on its levels. The reason for this is that since the real effective exchange rate variable is an index, it is no possible to make cross country comparisons on the basis of the levels of the variable. ${ }^{12}$ Fixed effects estimation can somewhat mitigate this problem but it is not likely to fully address it in a satisfactory way. Note that this lack of cross country comparability also prevents us from estimating dynamic models for the real exchange rate where for example the changes in the variable of interest are

\footnotetext{
${ }^{9}$ This however would require that the main effect of remittances on the exchange rate is through the growth channel described above and that the country has a positive net foreign asset position.

10 This can occur if regional migration flows patterns are different and as result migrants remit for different purposes. Once again remittances that result in higher consumption will likely lead to an appreciation of the real exchange rate whereas remittances that lead to higher investment may have less of an effect.

${ }^{11}$ The remittances data are as in Aggarwal, Demiguc-Kunt, and Martinez Peria (2005) and the data come from the IMF's World Economic Outlook 2005 database. As for the rest of the variable, the terms of trade and per capita growth variables come from the World Development Indicators database, government consumption is from the World Economic Outlook 2005 database, and the world real interest is computed using the US interest rate (6month) and US producer price index from the International Financial Statistics.

${ }^{12}$ For example, the base year all the countries in the sample will have the same value, say 100; clearly, this does not imply that the real exchange rate level is comparable among them.
} 
related in addition to a control set, to the lagged endogenous variable so that one can capture mean reverting forces. The need to work with the first difference of the real exchange rate in turn implies that it is probably more appropriate to work with transformations of the original explanatory variable set. For example, rather than working with the levels of the terms of trade we work with their changes. Similarly, rather than working with GDP per capita we work with GDP growth rates.

A third difference with respect to Amuedo-Dorantes and Pozo (2004) is that we explore whether the results are robust to excluding GDP growth from the specification. The reason for this is that if remittances affect per capita growth and growth in turn affects the real exchange rate either à la Balassa-Samuelson or as in portfolio models, then econometric models that control for the evolution of income levels will not capture the full impact of remittances on the exchange rate (i.e. these models will produce results that are biased).

Fourth, our variable of interest is the changes in the remittances to GDP ratio whereas Amuedo-Dorantes and Pozo (2004) use remittances per capita. We believe that our choice is more appropriate in this context since it is likely to better capture the importance of remittances flows relative to the size of the economy (see also the annex). Finally, we also explore the extent to which the results for the real exchange rate are driven by changes in fundamentals and changes in the disequilibrium level. In this regard, we also present the results of a regression model that has as dependent variable an index of overvaluation based on Dollar (1992). To better understand the idea here, consider the following decomposition of the real exchange rate:

$$
q_{i t}=\bar{q}_{i t}+\hat{q}_{i t}
$$

where the bar on top of the variable indicates that an equilibrium value and the hat indicates a disequilibrium value. Then our strategy is based on the following regression:

$$
\Delta \hat{q}_{i t}=\kappa^{\prime} x_{i t}+\delta \Delta R_{i t}+\eta_{i}+u_{i t}
$$

Note that same simple manipulations of (1), (3) and (4) yield

$$
\Delta \bar{q}_{i t}=\Delta q_{i t}-\Delta \hat{q}_{i t}=(\kappa-\omega)^{\prime} x_{i t}+(\beta-\delta) \Delta R_{i t}+\text { error }
$$

so that from those regressions it is possible to recover the impact of remittances on the real equilibrium exchange rate.

\section{Econometric issues}

One problem that has to be faced before proceeding with the results of the estimation is the potential reverse causality from the real exchange rate to the remittances. Rajan and Subramanian (2005) note that countries that had overvalued exchange rates in the early 1990s received significantly lower remittances during the rest of the decade, and argue that it is plausible that if emigrants perceive an overvalued exchange rate, they may switch to sending goods directly. Similarly, emigrants can find more attractive sending remittances home following devaluation. In this regard, the expected positive causal relationship from remittances 
to the real exchange rate can be contaminated by a possible negative causal relation from changes in the real exchange rate to remittances. To somewhat address the potential reverse causality one can resort to IV estimation techniques and follow Aggarwal, Demirguc-Kunt, and Martinez Peria (2005) who propose two instruments for remittances: the level of output per capita of the host countries of migrant workers weighted by (i) distance between sending and receiving country and (ii) share of migrants of the receiving country in the sending country. In the empirical section below we use as instruments the (logged) levels and first differences of these two variables.

\section{Results}

\section{Remittances and the real exchange rate}

We start this section by presenting results corresponding to equation (1) under the restriction that the GDP growth rate does not enter in the equation, so that if remittances affect the exchange rate though their impact on growth this specification should capture their full impact. Column (I) of Table 2 suggests that indeed remittances would lead to a real exchange rate appreciation. Judging from point estimates, this basic model indicates that a 1 percentage point increase in the remittances to GDP ratio would lead to a real effective exchange rate appreciation of about 2.5 percent. Thus a doubling of the remittances to GDP ratio would lead to a real exchange rate appreciation of 5 percent. This estimate is much lower than the estimate of Amuedo-Dorantes and Pozo (2004), which as noted above would be slightly above 22 percent.

The estimates for the rest of the variables in this specification carry the expected signs although they are not always statistically different from zero. As discussed above, higher interest rates, and improvements in the terms of trade would in principle be associated with a higher real exchange rate. Regarding government consumption, if it falls disproportionately on nontradables goods (not very unreasonable) Balassa-Samuelson considerations would also suggest that it contributes to an appreciation. As for the impact of including GDP growth among the explanatory variables, column (II) indicates only a modest impact. In fact, even if the point estimate of the parameter of GDP growth is negative, it is never significantly different from zero.

Could these results be biased by reverse causality considerations? As discussed above, in principle one would expect that a potential causal relationship from the real exchange rate to remittances would introduce a negative bias in the previous results. However, missing variables considerations could make the sign of the bias go in any direction. Columns (III), (IV) and (V) explore whether the findings in columns (I) and (II) are robust to the use of IV estimation techniques using as instruments the variables described in Section III.2. These specifications indicate that, if anything, the impact of remittances on the real exchange rate would be much larger than in the models that treat remittances as an exogenous variable (i.e. the OLS estimates seem to be affected by a negative bias). In fact, while the estimates in column (I) suggested an impact parameter of about 2.5 with the IV specification the estimated parameter is more than five-fold (between 18 and 24 depending on the instrument set used).

Table 2 includes two specification tests accompanying out IV models. The first is the Anderson canonical correlations LR test and it assesses relevance of the instruments. A rejection 
of the null hypothesis in this test indicates that the model is identified and that the instruments are relevant. The second test assesses the validity of the instruments by means of a Sargan test of overidentifying restrictions. The null hypothesis is that the excluded instruments are not correlated with the error term and rejection of the null hypothesis points to the presence of not valid instruments. Although column (V) might indicate some problems with Aderson test, the results do not appear to indicate serious concerns with these tests. Columns (VI) to (X) of table 2 reports the results of extending the previous basic model as in equation (2); that is, it reports the results of a model that allows remittances to have a different impact on the real effective exchange rate in Latin America and in the rest of the world. The estimates of these exercises indicate that the null hypothesis that the impact of remittances on the exchange rate of the Latin American countries is not different than in the rest of the world cannot be rejected in any case. In fact, the t-statistic of the interaction of remittances and a dummy for the Latin American countries hovers around .5 (in absolute value) not coming close to rejection of the null.

\section{Remittances and real exchange rate misalignment}

What's the driver behind the observed real exchange rate appreciation? Is it a reaction of the real equilibrium exchange rate to a positive shock and hence a natural adjustment to a new equilibrium? Or instead, is it a temporary deviation from the equilibrium? We now empirically assess this issue and proceed to regress a measure of real exchange rate misalignment (the cyclical component that results from filtering the real exchange rate using the Hodrick Prescott filter with $\lambda=100$ ) on the explanatory variables. That is, we now estimate equation (3), using $\hat{q}_{i t}$ rather than $q_{i t}$. The results of this exercise are presented in table 3.

Inspection of this table indicates that the parameter of remittances continues to be significant. That is, it would be difficult to defend that all the changes in the real exchange rate would be driven by an adjustment towards the new equilibrium. As in table 2 the interaction of remittances with a Latin American dummy continues to be not significantly different from zero and hence we cannot reject the null hypothesis that Latin America is not different from the rest of the world in this case. On the other hand the point estimates of the impact of remittances on the degree of real exchange rate misalignment are always smaller than the point estimates of the impact of remittances on the observed real exchange rate, an indication that the observed changes in the real exchange rate are a combination of adjustment towards the new equilibrium and some apparent overshooting.

For example, the basic models in columns (I) and (II) and (VI) and (VII) would suggest that about one half of the observed change in the real exchange rate would be due to adjustments in the real equilibrium exchange rate (i.e. an estimated impact of remittances on the real exchange rate of 2.1-2.5 against an estimated impact of about 1.3 on the measure of misalignment change). On the other hand, the IV based estimates would suggest that less than one-third of the fluctuations in the real exchange rate would be due to equilibrium adjustments (estimates of $\beta$ in the 17-30 range in table 2 and of 10-20 in table 3). 
Table 2. The impact of remittances on the real exchange rate

\begin{tabular}{|c|c|c|c|c|c|c|c|c|c|c|}
\hline & $\begin{array}{l}\text { (I) } \\
\text { FE }\end{array}$ & $\begin{array}{l}\text { (II) } \\
\text { FE }\end{array}$ & $\begin{array}{c}\text { (III) } \\
\text { FE/IV1 }\end{array}$ & $\begin{array}{c}\text { (IV) } \\
\text { FE/IV1 }\end{array}$ & $\begin{array}{c}(\mathrm{V}) \\
\text { FE/IV2 }\end{array}$ & $\begin{array}{c}\text { (VI) } \\
\text { FE }\end{array}$ & $\begin{array}{c}\text { (VII) } \\
\text { FE }\end{array}$ & $\begin{array}{c}\text { (VIII) } \\
\text { FE/IV1 }\end{array}$ & $\begin{array}{c}(\mathrm{IX}) \\
\text { FE/IV1 }\end{array}$ & $\begin{array}{c}(\mathrm{X}) \\
\text { FE/IV2 }\end{array}$ \\
\hline Change Remittances & 2.44 & 2.42 & 17.78 & 18.04 & 24.06 & 2.04 & 2.06 & 21.43 & 20.07 & 29.39 \\
\hline$(\%$ of GDP) & 3.26 & 3.22 & 2.93 & 2.85 & 2.35 & 1.95 & 1.96 & 2.31 & 2.31 & 1.96 \\
\hline Change Remittances x LAC & & & & & & 0.83 & 0.75 & -7.87 & -4.78 & -10.53 \\
\hline$(\%$ of GDP $)$ & & & & & & 0.55 & 0.49 & -0.54 & -0.34 & -0.52 \\
\hline Interest Rates & 0.01 & 0.01 & 0.02 & 0.02 & 0.02 & 0.01 & 0.01 & 0.01 & 0.01 & 0.01 \\
\hline (US 6-month rate) & 1.27 & 1.24 & 1.01 & 1.00 & 1.00 & 1.32 & 1.29 & 0.43 & 0.56 & 0.44 \\
\hline Terms of Trade & 0.28 & 0.27 & 0.24 & 0.24 & 0.33 & 0.28 & 0.27 & 0.28 & 0.26 & 0.39 \\
\hline (Change, \%) & 2.96 & 2.81 & 1.38 & 1.37 & 1.32 & 2.91 & 2.77 & 1.42 & 1.39 & 1.34 \\
\hline Government consumption & 0.62 & 0.69 & 1.32 & 1.31 & 1.03 & 0.61 & 0.68 & 1.26 & 1.29 & 0.93 \\
\hline$(\%$ of GDP $)$ & 1.43 & 1.54 & 1.52 & 1.50 & 0.85 & 1.40 & 1.51 & 1.38 & 1.44 & 0.71 \\
\hline Growth & & 0.10 & & -0.03 & -1.00 & & 0.09 & & 0.00 & -1.07 \\
\hline$(\%)$ & & 0.86 & & -0.13 & -1.03 & & 0.83 & & 0.02 & -1.01 \\
\hline Number of observations & 250 & 250 & 221 & 221 & 221 & 250 & 250 & 221 & 221 & 221 \\
\hline Anderson canon. Correlation (p-val) & & & 0.05 & 0.07 & 0.17 & & & 0.07 & 0.05 & 0.1 \\
\hline Sargan test of overidentification ( $p$-val) & & & 0.47 & 0.48 & 0.85 & & & 0.37 & 0.31 & 0.89 \\
\hline
\end{tabular}

The table reports the results of regressing the changes in the logged real effective exchange rate on the variables in the first column, allowing for fixed effects. IV1 Indicates that remittances are treated as endogenous; IV2 indicates that remittances and growth are treated as endogenous. Instruments are in both cases the level and first differences of (logged) output per capita of the host countries of migrant workers weighted by (i) distance between sending and receiving country and (ii) share of migrants of the receiving country in the sending country. t-statistics in italics. Source: Author's calculations. 
Table 3. The impact of remittances on real exchange rate misalignment

\begin{tabular}{|c|c|c|c|c|c|c|c|c|c|c|}
\hline & $\begin{array}{l}\text { (I) } \\
\text { FE }\end{array}$ & $\begin{array}{l}\text { (II) } \\
\text { FE }\end{array}$ & $\begin{array}{c}\text { (III) } \\
\text { FE/IV1 }\end{array}$ & $\begin{array}{c}\text { (IV) } \\
\text { FE/IV1 }\end{array}$ & $\begin{array}{c}\mathrm{V}) \\
\mathrm{FE} / \mathrm{IV} 2\end{array}$ & $\begin{array}{c}\text { (VI) } \\
\text { FE }\end{array}$ & $\begin{array}{c}\text { (VII) } \\
\text { FE }\end{array}$ & $\begin{array}{c}\text { (VIII) } \\
\text { FE/IV1 }\end{array}$ & $\begin{array}{c}\text { (IX) } \\
\text { FE/IV1 }\end{array}$ & $\begin{array}{c}\mathrm{X}) \\
\mathrm{FE} / \mathrm{IV} 2\end{array}$ \\
\hline Change Remittances & 1.29 & 1.31 & 10.28 & 11.14 & 14.19 & 1.33 & 1.33 & 14.87 & 14.62 & 19.83 \\
\hline$(\%$ of GDP $)$ & 2.30 & 2.31 & 2.66 & 2.65 & 2.27 & 1.69 & 1.68 & 2.36 & 2.42 & 2.05 \\
\hline Change Remittances x LAC & & & & & & -0.08 & -0.04 & -9.89 & -8.23 & -11.31 \\
\hline$(\%$ of GDP $)$ & & & & & & -0.07 & -0.03 & -1.00 & -0.85 & -0.86 \\
\hline Interest Rates & 0.02 & 0.02 & 0.02 & 0.02 & 0.02 & 0.02 & 0.02 & 0.01 & 0.01 & 0.01 \\
\hline (US 6-month rate) & 2.65 & 2.65 & 1.97 & 1.92 & 1.69 & 2.62 & 2.62 & 0.77 & 0.89 & 0.67 \\
\hline Terms of Trade & 0.26 & 0.26 & 0.24 & 0.24 & 0.26 & 0.26 & 0.26 & 0.28 & 0.27 & 0.31 \\
\hline (Change, \%) & 4.04 & 4.07 & 2.40 & 2.31 & 1.98 & 4.03 & 4.05 & 2.36 & 2.34 & 1.93 \\
\hline Government consumption & 0.29 & 0.26 & 0.67 & 0.64 & 0.50 & 0.29 & 0.26 & 0.60 & 0.59 & 0.41 \\
\hline$(\%$ of GDP) & 0.87 & 0.77 & 1.22 & 1.10 & 0.69 & 0.87 & 0.77 & 0.97 & 0.96 & 0.48 \\
\hline Growth & & -0.05 & & -0.13 & -0.61 & & -0.05 & & -0.07 & -0.67 \\
\hline$(\%)$ & & -0.58 & & -0.89 & -1.05 & & -0.58 & & -0.44 & -1.01 \\
\hline Number of observations & 250 & 250 & 221 & 221 & 221 & 250 & 250 & 221 & 221 & 221 \\
\hline Anderson canon. Correlation (p-val) & & & 0.05 & 0.06 & 0.15 & & & 0.06 & 0.05 & 0.09 \\
\hline Sargan test of overidentification ( $\mathrm{p}$-val) & & & 0.31 & 0.44 & 0.6 & & & 0.39 & 0.44 & 0.85 \\
\hline
\end{tabular}

The table reports the results of regressing the changes in the estimated real effective exchange rate misalignment on the variables in the first column, allowing for fixed effects. IV1 Indicates that remittances are treated as endogenous; IV2 indicates that remittances and growth are treated as endogenous. Instruments are in both cases the level and first differences of (logged) output per capita of the host countries of migrant workers weighted by (i) distance between sending and receiving country and (ii) share of migrants of the receiving country in the sending country. t-statistics in italics. Source: Author's calculations. 


\section{Tax structure and competitiveness}

We have mentioned earlier that the Dutch disease effects are exacerbated by the domestic supply response. Inflationary pressure for domestic non-tradables (and thus real exchange rate appreciation) is directly linked to what happens to factors supply and in particular to labor supply. Econometric evidence shows that labor supply tends to shrink in response to rising remittances. Within the margins of narrow fiscal spaces, can governments implement policies that counteract this negative labor supply and thus mitigate wage and real exchange rate increases? ${ }^{13}$

A policy response considered here consists of a contemporary reduction of payroll taxes and an increase in sales taxes, i.e. a partial switch from direct taxes to indirect taxes. Taxing remittances directly is not a viable policy option for, at least, two reasons: the income generating the remittances has already been taxed at the origin and the double taxation would increase the agents' incentives to transfer money through the black market; secondly, remittances are an important source of household income and taxing them could increase the vulnerability of households to income shocks. A reduction in payroll taxes is a better alternative policy tool to limit the negative labor supply response following a remittance shock. From the workers' point of view, lower payroll taxes directly provide greater incentives to work through higher wages. This policy also reduces the wages paid by the employers and thereby increases their labor demand. Payroll tax (or other direct tax) cuts should be considered as illustrative for any set of policies aiming at stimulating labor supply. ${ }^{14}$

With the help of a Computable General Equilibrium (CGE) model, we have tested this policy for Jamaica, a country that during the 1990s witnessed, on the one hand, a combination of lagging participation rates (especially for women) and rising real wages and, on the other hand, a remarkable increase in international remittance inflows, reaching almost 20 percent of GDP in 2003.

Using data for Jamaica, we test whether a 25 percent cut in payroll tax is a viable policy to sterilize the reduction in labor supply induced by a 10 percent increase in remittances ${ }^{15}$. The main results are shown in table 4. Consider initially the effect of higher remittances in the first column. Total labor income change is comprised of two components: on the one hand, labor income falls because more non-labor income encourages households to consume more leisure, but on the other hand, reduced labor supply is accompanied by increased labor demand (given the increased demand for goods) and wages rise. The change in wages adds a set of second-order effects to the mentioned change in labor supply, since an increase in the wage rate raises the

\footnotetext{
${ }^{13}$ The following discussion draws heavily on Bussolo and Medvedev (2007)

${ }^{14}$ Here we assume that the government through a cut of the payroll tax is directly able to stimulate supply by reducing the wedge between wages paid by the employers and those received by the workers; however the actual fiscal instruments at the government disposal may be less direct, and revenues from payroll taxes may not be easily substituted by revenues from other taxes. Less direct ways of affecting labor market outcomes may consist of a set of microeconomic interventions aiming at increasing markets flexibility and labor productivity (see below).

${ }^{15}$ This increase in remittance inflows is not very large considering the rapid pace of remittance growth over the last decade. Since remittances represent approximately one-fifth of Jamaican total household income, a 10 percent remittance shock raises total household income by 2 percent.
} 
opportunity cost of leisure and, as long as the substitution effect dominates the income effect, encourages households to supply more labor. Given that skilled and unskilled workers are employed with different intensities across sectors and that final demand does not increase equally for all goods and services, the general equilibrium effects will differ across the types of workers. In this specific case for Jamaica the relative wage of unskilled workers increases slightly.

Overall, total labor supply declines by 8,000 workers, which represents about one percent of the overall employment. Greater household income generates more demand for consumption goods and services which is satisfied by a combination of increased domestic supply and import flows. International prices are not affected by this surge in Jamaican imports, whereas prices of the domestically produced goods rise in response to domestic market conditions. The erosion of Jamaican competitiveness is summarized in a real exchange rate appreciation of almost 1 percent.

Consider now the effects of the 25 percent cut in the payroll tax. The starting point is the equilibrium attained after the 10 percent remittance shock, and the results, as percentage changes from that previous simulation, are presented in the second column of Table 4 . The third column contains the cumulative change from the initial equilibrium (i.e. the total effect of the remittance shock and the policy response). The reduction in payroll taxes increases after-tax wages. In this new situation, households choose to reduce their consumption of more expensive leisure and increase their labor supply. This increase does not fully neutralize the negative withdrawal due to the remittance shock, yet it significantly corrects its initial effect: 72 percent and 47 percent of the remittance-induced reduction in labor supply for unskilled and skilled labor is offset by the payroll tax change.

As a result of increased labor force participation and higher wages, household labor income rises by 2.2 percent, with a cumulative increase of 3.7 percent after both simulations. Household total income increases at a slower pace, because labor is not the only income source for the households. The reduction of payroll taxes benefits employers by reducing their labor costs. This counterbalances the remittance-induced appreciation of the real exchange rate by lowering domestic prices and exports rise and imports fall.

These basic results are unaffected when revenue losses from payroll taxes are compensated by increasing sales taxes. Sales taxes affect consumption choices and should be preferred to direct increases of income taxes, which could potentially deter future or even current flows of remittances. Increasing taxes on international trade is not recommendable, since protectionism is likely to reduce welfare at home.

In sum, a reduction in payroll taxes compensated by an increase in sales taxes appears to counteract many of the undesirable effects of increased remittance inflows: lower rates of labor force participation and reduced export competitiveness. However, this switch of direct-toindirect taxation can have relevant income distribution consequences which we need to be taken into consideration. Although in principle, indirect taxes tend to be regressive and their increase should then have worse consequences for poorer individuals, for the case of Latin America Goñi, Lopez and Serven (2006) have shown that the overall (direct and indirect) tax redistribution is 
minimal and that only through transfers some Latin American countries achieve some redistribution through the fiscal system.

Table 4 Macroeconomic results of a remittance shock and a payroll tax for Jamaica

\begin{tabular}{lccc}
\hline & $\begin{array}{c}\text { Remittance } \\
\text { effect, percent } \\
\text { change from } \\
\text { initial } \\
\text { equilibrium }\end{array}$ & $\begin{array}{c}\text { Tax effect, percent } \\
\text { change from } \\
\text { remittance shock }\end{array}$ & $\begin{array}{c}\text { Total effect, } \\
\text { percent } \\
\text { change from } \\
\text { initial } \\
\text { equilibrium }\end{array}$ \\
\hline Remittances & 10.00 & 0.00 & 10.00 \\
Total household income & 2.04 & 1.16 & 3.22 \\
Household labor income & 1.43 & 2.20 & 3.67 \\
CPI & 0.54 & -0.03 & 0.50 \\
Real exchange rate & 0.88 & -0.08 & 0.80 \\
\hline Real GDP & -0.37 & 0.10 & -0.26 \\
$\quad$ Private consumption & 1.50 & 1.19 & 2.71 \\
$\quad$ Investment & -0.06 & -2.58 & -2.63 \\
$\quad$ Exports & -2.70 & 0.05 & -2.66 \\
$\quad$ Imports & 0.81 & -0.06 & 0.75 \\
\hline Unskilled labor supply & -0.76 & 0.55 & -0.21 \\
Skilled labor supply & -0.84 & 0.40 & -0.45 \\
Unskilled wage & 2.31 & 2.08 & 4.45 \\
Skilled wage & 2.26 & 1.99 & 4.29 \\
\hline Memo & & & \\
Absolute change in unskilled labor & & & $-1,061$ \\
supply & $-3,822$ & 2,761 & $-2,424$ \\
Absolute change in skilled labor & $-4,563$ & 2,139 & \\
supply & & &
\end{tabular}

\section{Conclusions}

In this paper we have reviewed the impact of workers' remittances on the real exchange rate and concluded that surges in workers' remittances appear to contribute to real exchange rate appreciations and in this regard our tests do not detect any differential impact for Latin America. Moreover, we have also explored whether the estimated appreciation would be consistent with the natural appreciation that one would expect in the real equilibrium exchange rate following a positive shock, or instead whether the observed changes are more likely to be driven by changes in the misalignment component. The findings of the paper would indicate that not all of the observed changes are consistent with the equilibrium changing according to the new fundamentals.

Against this background a natural question that arises is what policy makers can do about that real appreciation and therefore about the potential loss in international competitiveness that may come with large remittance flows to the region. We now discuss these issues. 
- Rein in fiscal policy. Fiscal restraint is probably one of the only tools that governments have to prevent overheating, and avoid a real exchange rate appreciation in the context of a surge in international workers remittances. Beyond the theoretical reasoning in support of this tool, ${ }^{16}$ the estimates presented in this paper indicate that increases in the government consumption to GDP ratio would be associated with real appreciations. Yet, it must also be noted that our estimates indicate that the impact of this variable tends to be much lower than the impact of remittances. In other words, the adjustment needed to stabilize the real exchange rate may be quite large and therefore constrained by political economy considerations.

- Limit the use of sterilizing operations. One natural question in this context is the extent to which countries should try to sterilize the remittances inflows. Sterilization can be defined as the exchange of government paper for foreign exchange so that the monetary base is insulated from the remittances flows (other sterilization-type policies would include increases in reserve requirements on all or selected parts of bank deposits). Sterilizing operations could be effective if used over the short run, but may prove infeasible if needed on a sustained basis for two main reasons. First, the magnitude of the remittances would make the quasi-fiscal costs of sterilizing these flows untenable. Large remittances inflows coupled with Latin American spreads that for the ten top receiving countries range from $141 \mathrm{bp}$ in Mexico to almost $300 \mathrm{bp}$ in Jamaica would in fact make this alternative extremely expensive (to the point that even assuming no pressure on the domestic interest rate, in a number of countries the cost of sterilizing the inflows in full would be measured in tenths of percentage points). Second, sterilization would possibly put pressure on the domestic interest rates something that may attract other type of inflows in search of high returns and this in turn would put more pressure on the exchange rate. In this regard, if sterilization is implemented without fiscal adjustment, (i.e. tight money plus loose fiscal) it would not be unlikely to observe a further appreciation.

- Microeconomic interventions. Although the thrust of responses to surges on capital inflows of any type (including remittances) may be expected to be in the macro policy arena, there are a number of microeconomic interventions that governments can implement. The discussion in section II above suggested that rigidities in labor and product markets could contribute to a real appreciation in this context because of BalassaSamuelson type of arguments. Thus efforts aimed at making domestic markets more efficient could also ease exchange rate pressures. More generally, microeconomic interventions that make the economy more competitive could somewhat offset the real exchange rate pressures.

- Consider a shift from payroll taxes to VAT or sales taxes. As documented in Acosta and Fajnzylber (2007), remittances appear to have a negative impact on labor supply, something that in turn may exacerbate the real exchange rate appreciation and the loss in competitiveness of the economy. Yet, as discussed above a reduction in payroll taxes

\footnotetext{
${ }^{16}$ That fiscal expansions (contractions) lead in the presence of perfect capital mobility to a real exchange rate appreciation (depreciation) is a typical result of the basic IS-LM model.
} 
compensated by an increase in VAT/sales taxes appears to counteract many of the undesirable effects of increased remittance inflows.

- Accept some appreciation. Taking together all the elements in the paper and to the extent that fiscal adjustment and microeconomic interventions may not be enough to correct the upward pressures in the real exchange rate, it is possible that Latin American policy makers will have to accept some real appreciation, especially in those countries with substantial flows. This loss of competitiveness, however, should not be viewed as a cost associated to remittances but rather as a reflection of the changing conditions brought by the significant remittances flows. 


\section{References}

Acosta, P., C. Calderon, P. Fajnzylber, and H. Lopez (2007): "What is the Impact of International Remittances on Poverty and Inequality in Latin America?", World Development, forthcoming.

Acosta, P., and P. Fajnzylber (2007): "Remittances and Household Behavior", Mimeo, The World Bank.

Aggarwal, R., A. Demirguc-Kunt, and M. S. Martinez Peria (2005): “Do Workers' Remittances Promote Financial Development?" mimeo, The World Bank, Washington, DC.

Alberola, E., S. G. Cervero, H. López, and A. Ubide (1999): "Global equilibrium exchange rates: euro, dollar, 'ins,' 'outs' and other major currencies in a panel cointegration framework", IMF Working Paper No. 175, International Monetary Fund, Washington, DC.

Alberola E., S. G. Cervero, H. López and A. Ubide (2002): “Quo vadis euro?", European Journal of Finance 8 (4), 352-70.

Alberola, E. and H. López (2001): "Internal and external exchange rate equilibrium in a cointegration framework. An application to the Spanish peseta", Spanish Economic Review, 3(1), $23-40$.

Amuedo-Dorantes, C. and S. Pozo (2004): "Workers' Remittances and the Real Exchange Rate: A Paradox of Gifts", World Development 32: 1407-1417.

Annabi, N. (2003): "Modeling Labor Markets in CGE Models: Endogenous Labor Supply, Unions, and Efficiency Wages". Poverty and Economic Policy (PEP) network working paper.

Armington P. S (1969), “ A Theory of Demand for Products Distinguished by Place of Production”, IMF Staff Papers, 16:159-178.

Balassa, B. (1964): “The Purchasing Power Parity Doctrine: A Reappraisal," Journal of Political Economy, 72, 584-96.

Barzel, Y., and R. McDonald (1973): “Assets, Subsistence, and the Supply Curve of Labor", American Economic Review 63(4):621-633.

Bussolo, M. D. Medvedev (2007): "Do remittances have a flip side? A general equilibrium analysis of remittances, labor supply responses and policy options for Jamaica" Policy Research Working Paper No. 4143, World Bank, Washington DC

De Melo, J. And D. Tarr (1992): "General Equilibrium Analysis of US Foreign Trade Policy" MIT Press. 
Dollar, D. (1992): "Outward-Oriented Developing Economies Really Do Grow More Rapidly: Evidence from 95 LDC's, 1976-1985," Economic Development and Cultural Change 40(3), 52344.

Fajnzylber, P. and J. H. Lopez (2006): "Close to Home: The Development Impact of Remittances in Latin America", The World Bank.

Frenkel, J. and M. Mussa (1985): "Asset Markets, Exchange Rates, and the Balance of Payments", in R.W. Jones, P.B. Kenen (eds.) Handbook of International Economics Vol. 2, Ch. 14.

Goñi, E., H. Lopez and L. Serven (2006): "Fiscal reform for social equity in Latin America", mimeo. The World Bank.

International Monetary Fund (2005): "World Economic Outlook" International Monetary Fund, Washington, DC.

Mussa, M. (1984): "The Theory of Exchange rate Determination", in J. Bilson, and R. Marston (eds), Exchange Rate Theory and Practice, NBER Conference Report, University of Chicago Press, Chicago.

Perry, G., O. Arias, H. Lopez, W. Maloney, and L. Servén (2006): "Poverty Reduction and Growth: Virtuous and Vicious Circles", The World Bank, Washington, DC.

Rajan, R., and A. Subramanian (2005): "What Undermines Aid's Impact on Growth?", mimeo, International Monetary Fund, Washington, DC.

Samuelson,P.A. (1964): "Theoretical Notes on Trade Problems," Review of Economics and Statistics, 46, 145-54.

Taubman, P., and M. Wachter (1986): "Segmented Labor Market" in Ashenfelter, O. and Layard P.R.G. (eds.) Handbook of Labor Economics, Vol.2. Amsterdam: North Holland.

World Bank (2003): “World Development Report 2003: Sustainable Development in a Dynamic World", The World Bank, Washington, DC.

World Bank (2006): "Global Economic Prospects: Economic Implications of Remittances and Migration", The World Bank, Washington D.C. 


\section{Technical Annex 1}

The argument that a real exchange rate appreciation is a natural outcome in the presence of remittances can be illustrated with a simple model of exchange rate determination. Here, we follow Alberola et al. (1999) and assume that there are two countries in the world, each producing two goods: one tradable (subscript $T$, in what follows) and one non-tradable $(N)$. The real exchange rate $(q)$ is defined as the relative price of domestic to foreign goods in the consumption basket, $p$ and $p^{*}$, respectively, ${ }^{17}$ expressed in domestic currency:

$$
q=p-\left(s+p^{*}\right)
$$

where $s$ is the $(\log )$ nominal exchange rate, defined as the price of foreign currency in terms of domestic currency. Thus, an increase in $q$ represents an appreciation of the real exchange rate.

The consumer price index (CPI) for each country is a weighted-average of the tradable, non-tradable, and imported (tradable) prices, all expressed in their own currency:

$$
\begin{aligned}
& p=\left(1-\alpha_{N}-\alpha_{T}\right) p_{T}+\alpha_{N} p_{N}+\alpha_{T}\left(s+p_{T}^{*}\right) \\
& p^{*}=\left(1-\alpha_{N}^{*}-\alpha_{T}^{*}\right) p_{T}^{*}+\alpha_{N}^{*} p_{N}^{*}+\alpha_{T}^{*}\left(p_{T}-s\right)
\end{aligned}
$$

where the $\alpha s$ are the weights of the respective goods in the consumer basket. Substituting these expressions in (1), assuming that $\alpha_{N}=\alpha_{N}^{*}$, and rearranging terms we obtain

$$
q=\left(1-\alpha_{T}-\alpha_{T}^{*}\right) q_{X}+\alpha_{N} q_{I}
$$

where:

- $q_{X}=\left[p^{T}-\left(s+p_{T}^{*}\right)\right]$ is the relative price of domestic to foreign tradables and

- $q_{I}=\left[\left(p_{N}-p_{T}\right)-\left(p_{N}^{*}-p_{T}^{*}\right)\right]$ is the price of non-tradables relative to tradables across countries.

The first component of (3) $\left(\left(1-\alpha_{T}-\alpha_{T}^{*}\right) q_{X}\right)$ captures the competitiveness of the economy and determines the evolution of the foreign asset position, while the second $\left(\alpha_{N} q_{I}\right)$ plays a central role in adjusting excess demand across sectors in the economy. Each relative price adjusts to achieve equilibrium in one of the markets, and hence we will denote $q_{X}$ and $q_{I}$ as the internal and the external relative prices, respectively. The equilibrium exchange rate $(\bar{q}$, where the bar denotes equilibrium values) will require simultaneous equilibrium in both markets, and thus it will be a combination of the equilibrium internal and external relative prices.

We next characterize the external and internal equilibrium of the economy.

\footnotetext{
${ }^{17}$ An asterisk denotes foreign variables.
} 


\section{External equilibrium}

Portfolio models of real exchange rate determination (Mussa 1984) focus on asset equilibrium, as defined by the attainment of agents' desired foreign asset stock. Over time, the accumulation of net foreign assets $(F)$ is given by the current account balance $(C A)$, which equals the trade balance $(X N)$, plus the net income that residents receive (or pay) on $F$, plus net current transfers from abroad $(T)$. For simplicity, we will assume that that the only transfers in this economy are international remittances $(R)$, so that we can write:

$$
\Delta F=C A=X N+i * F+T=C A=X N+i * F+R
$$

where $i^{*}$ is the international interest rate, which is assumed given. It will be more convenient to focus on the trajectory of the foreign asset stock relative to GDP, which can be written

$$
\Delta f=c a=x n+\left(i^{*}-g\right) f+r
$$

where $f, x n$ and $r$ denote the ratios to GDP of the respective uppercase variables, and $g$ is the rate of GDP growth. If the Marshall-Lerner condition holds an increase in the relative price of domestic tradables $q_{X}$ shifts consumption toward foreign tradables and worsens the trade balance. Consistent with this interpretation, it is plausible to assume that the trade balance as a percentage of GNP $(x n)$ is given by:

$$
x n=-\gamma q_{x} \quad \gamma>0 .
$$

The capital account deficit reflects the desired rate of accumulation of net foreign assets by the home country, which is assumed to depend on the divergence between the current level of assets as a percentage of GNP $(f)$ and the desired equilibrium level $(\bar{f})$, itself determined by exogenous factors such as saving preferences and demographics which will not be modelled here:

$$
\Delta f=c a=a(\bar{f}-f) \quad a>0 .
$$

Equation (7) indicates that if the actual net foreign asset position is below its desired level, agents will accumulate assets to reach the target; conversely, if $f$ is greater than $\bar{f}$ agents will be reduce their asset holdings until they reach $\bar{f}$.

Equating (A7) and (A5) after using (A6), and solving for $q_{x}$ we get:

$$
q_{x}=a \gamma(f-\bar{f})+\left(i^{*}-g\right) / \gamma f+1 / \gamma r .
$$

Equation (A8) shows that the external real exchange rate depends on (i) the divergence between current and equilibrium asset holdings; on (ii) the current stock of net foreign assets $f$; and (iii) on the ratio of remittances to GDP. Defining the equilibrium external real exchange rate $\bar{q}_{X}$ as 
that consistent with $f=\bar{f}$ (i.e. the exchange rate consistent with asset holdings at their equilibrium level) it follows that

$$
\bar{q}_{X}=\left(i^{*}-g\right) / \gamma \bar{f}+1 / \gamma r
$$

From equation (A9) it follows that (i) improvements in the equilibrium net foreign asset position $\bar{f}$ would lead to a real exchange rate appreciation; (ii) increases in the international interest rate $i^{*}$ would also lead to a real exchange rate appreciation; (iii) a higher growth rate would be associated with a lower equilibrium real exchange rate; and (iv) increases in the remittances to GDP ratio would be associated with a real exchange rate appreciation.

\section{Internal equilibrium}

The differential behaviour of sectoral relative prices between countries determines the evolution of the internal real exchange rate. Sectoral prices are in turn related to the evolution of sectoral productivity. These notions can be illustrated using a simple model with two production factors, labor (L) and capital (K). Output in each sector is determined by a Cobb-Douglas production technology:

$$
\begin{aligned}
& Y_{N}=A_{N} L_{N}{ }^{\delta} K_{N}{ }^{1-\delta} \\
& Y_{T}=A_{T} L_{T}{ }^{\theta} K_{T}{ }^{1-\theta},
\end{aligned}
$$

where $0<\theta, \delta<1$ represent the intensity of labor in each sector. Labor is perfectly mobile between sectors (but not across countries), implying nominal wage equalization:

$$
W_{T=} W_{N}=W
$$

Labor is paid the value of its marginal product $\partial Y_{i} / \partial L_{i}=W / P_{i}$. Under Cobb-Douglas technology the ratio of marginal productivities is proportional to the ratio of average productivities:

$$
\frac{\partial Y_{T} / \partial L_{T}}{\partial Y_{N} / \partial L_{N}}=\frac{\theta Y_{T} / L_{T}}{\delta Y_{N} / L_{N}}
$$

From (A12) it follows that the (log) sectoral price differential is equal to the labor productivity differentials plus a drift capturing the relative intensity of labor. Expressing with lower case the natural logarithms of sectoral labor productivities, (A12) reduces to

$$
\bar{p}_{N}-\bar{p}_{T}=\log (\theta / \delta)+\left[\left(y_{T}-y_{N}\right)\right]
$$

Neglecting constant terms and denoting $n=\left[\left(y_{T}-y_{N}\right)-\left(y_{T}^{*}-y_{N}^{*}\right)\right]$, the internal equilibrium exchange rate is just:

$$
\bar{q}_{I}=\bar{n} .
$$


Thus in line with the argument put forward by Balassa (1964) and Samuelson (1964), productivity differentials between the tradable and non tradable sectors relative to the foreign country will also affect the evolution of the real exchange rate. In particular, productivity gains in the domestic tradable sector relative to the domestic non tradable, would result in a real exchange rate appreciation.

How do remittances operate in this context? If the home country spends part of the remittances on nontraded goods, this additional demand will draw labor out of the export sector. Since from (A10) $\partial y / \partial L<0$, then it follows that the productivity of the nontradable sector $\left(y_{N}\right)$ will decline and the productivity of the tradable sector $\left(y_{T}\right)$ will increase. That is, we would expect that

$$
\left(y_{T}-y_{N}\right)=\eta r
$$

with $\eta>0$. As a result, remittances would also lead to a real exchange rate appreciation in the internal real exchange rate.

On the whole, the previous discussion indicates that remittances can be expected to affect both the internal and the external equilibrium of the economy and that higher remittances would be associated with real exchange rate appreciations.

\section{Technical Annex 2}

Initial benchmark data: the 2002 Jamaica SAM

The 2002 SAM has been assembled from various sources and includes 22 sectors, 22 commodities, 3 factors (skilled and unskilled labor and composite capital), an aggregate household account, government, savings-investment, taxes, tariffs, and the rest of the world (see Table 5). In order to construct this SAM, we relied on published STATIN data (national accounts and disaggregated GDP by sector), a 2000 SAM for Jamaica constructed by International Food Policy Research Institute (IFPRI), the 2002 Labor Force Survey, the 2002 Survey of Living Conditions, and the UN COMTRADE and TRAINS databases.

Macro SAM. In order to build the macroeconomic SAM, we relied mainly on the national accounts data from STATIN. We have followed this sectoral detail with one exception: we have aggregated "other manufacturing"-a very small sector-with "metal products and machinery." Since the value-added taxes are applied equally to domestically produced goods and imports, we impose the VAT on commodities rather than activities for simplicity. STATIN data combines taxes on international trade (tariffs) with other indirect taxes, and therefore we need additional information to separate indirect taxes from tariffs. We collect these data from UN COMTRADE and TRAINS databases. We use COMTRADE for trade flows (imports and exports) at a disaggregated level, and TRAINS for applied tariff rates in the same commodity groups. This allows us to calculate the overall tariff revenue, and subtract it from other taxes. 
Table 5: List of accounts for Jamaica SAM (2002)

\begin{tabular}{l|l} 
Production sectors and Commodities & Factors of Production \\
\hline 1 Export Crops & 23 Skilled Labor \\
2 Food Crops & 24 Unskilled Labor \\
3 Livestock & 25 Capital and Land \\
4 Forestry Fishing & Institutions and other accounts \\
\cline { 2 - 2 } 5 Mining & 26 Household \\
6 Food Products & 27 Government \\
7 Processed Sugar & 28 Investment and Savings \\
8 Beverages and Tobacco & 29 Indirect taxes \\
9 Textiles and Clothing & 30 Tariffs \\
10 Wood Products & 31 USA \\
11 Paper and Print & 32 European Union \\
12 Refined Oil & 33 Rest of the World \\
13 Chemicals & 34 Balance of Payment \\
14 Capital Goods & \\
15 Electricity and Water & \\
16 Construction & \\
17 Commerce & \\
18 Transport & \\
19 Financial and Insurance Services & \\
20 Real Est. \& Business Services & \\
21 Government Services & \\
\hline
\end{tabular}

Value added. The disaggregation of total value added by sector is available from STATIN. We combine this information with the earlier IFPRI SAM to disaggregate total value added into capital, labor, and indirect tax components. We also take advantage of the information in the Labor Force survey to ensure that the labor value added by sector is consistent with the aggregate survey results. In order to ensure that all of these constraints are satisfied, we use the RAS technique to estimate the shares of labor, capital, and indirect taxes.

Taxes. We use the VAT tax rates reported in the IFPRI SAM and apply them to the value added calculated in the previous step. We then adjust tax collection by sector to get the VAT total consistent with the macro SAM. Payroll taxes are not explicitly identified in the SAM-they are calculated within the model using a universal the payroll tax rate.

Intermediate and final demand. We use the shares of intermediate consumption to total value added from the IFPRI SAM to obtain a table of input coefficients, which are then applied to our data. Household consumption shares by commodity are calculated from the Survey of Living Conditions, and are quite close to those reported in the IFPRI SAM. We assume that the government consumes only its own services. Aggregate investment (net of stock changes) is split into sectoral investment using coefficients from the IFPRI SAM.

International trade. Data on merchandise imports, exports, and tariffs is obtained from UN COMTRADE and UN TRAINS. In order to impute service imports and exports (which include tourism), we use the IFPRI SAM to disaggregate total service exports and imports.

The resulting social accounting matrix is quite unbalanced, although the imbalances are limited to the commodity rows and columns. We balance this SAM using a cross-enthropy 
approach which allows only the input-output coefficients to move (the input-output coefficients from the IFPRI SAM serve as a starting point). This implies that we trust our final demand estimates (which come from the survey and COMTRADE data) and allow the production structure to change slightly.

\section{A brief description of the CGE model}

Production. Output results from nested CES (Constant Elasticity of Substitution) functions that, at the top level, combine intermediate and value added aggregates. At the second level, the intermediate aggregates are obtained combining all products in fixed proportions (Leontief structure), and total value added is obtained by aggregating the primary factors. The full structure of production nests is shown in Figure 4.

Income Distribution and Absorption. Labor income and capital revenues are allocated to households according to a fixed coefficient distribution matrix derived from the original SAM. Private consumption demand, as well as labor supply decisions, is obtained through maximization of household specific utility function following the Linear Expenditure System (LES). Household utility is a function of consumption of different goods and leisure. Once total value of private consumption is determined, government and investment demand are disaggregated into sectoral demands according to fixed coefficient functions.

International Trade. The model assumes imperfect substitution among goods originating in different geographical areas.18 Import demand results from a CES aggregation function of domestic and imported goods. Export supply is symmetrically modeled as a Constant Elasticity of Transformation (CET) function. Producers allocate their output to domestic or foreign markets according to relative prices. Under the small country assumption, Jamaica is unable to influence world prices and its imports and exports prices are treated as exogenous. Assumptions of imperfect substitution and imperfect transformability grant a certain degree of autonomy of domestic prices with respect to foreign prices and prevent the model from generating corner solutions. Furthermore, they permit cross-hauling-a feature normally observed in real economies. The balance of payments equilibrium is determined by the equality of foreign savings (which are exogenous) to the value of the current account. With fixed world prices and capital inflows, all adjustments are accommodated by changes in the real exchange rates: increased import demand, due, for instance, to trade liberalization, must be financed by increased exports, and these can expand due to improved resource allocation. Import price decreases drive resources towards export sectors and contribute to falling domestic resource costs (or real exchange rate depreciation).

Factor Markets. Labor is divided into two categories: skilled and unskilled. These categories are considered imperfectly substitutable inputs in the production process. The labor market skill segmentation $^{19}$ has become a standard assumption in CGE modeling and it is easily justifiable for the case of Jamaica, where inequalities in educational endowments and access to education support this assumption. Skilled and unskilled labor types are then aggregated into a composite labor bundle which is then combined with composite capital (see production nest in Figure 4). In the standard version, composite capital and labor types are fully mobile across sectors; however, in a variant version, we assume that labor markets are segmented between agriculture and non-

\footnotetext{
${ }^{18}$ See Armington (1969) for details.

${ }^{19}$ See Taubman and Wachter (1986) for a general discussion of labor market segmentation.
} 
agriculture, with labor fully mobile within each of the two broad sectors, but fully immobile across them. The restrictive conditions of this second version are imposed on the modeling framework so that it mimics more closely the behavior of the economy in the short-term when factors are less mobile across sectors. Capital supply is fixed. Labor supply, for both the skilled and unskilled categories, is derived from utility maximization where individuals chose the optimal consumption level for both commodities and leisure time under their budget constraint.

Figure 4: Production structure of the Jamaica CGE model

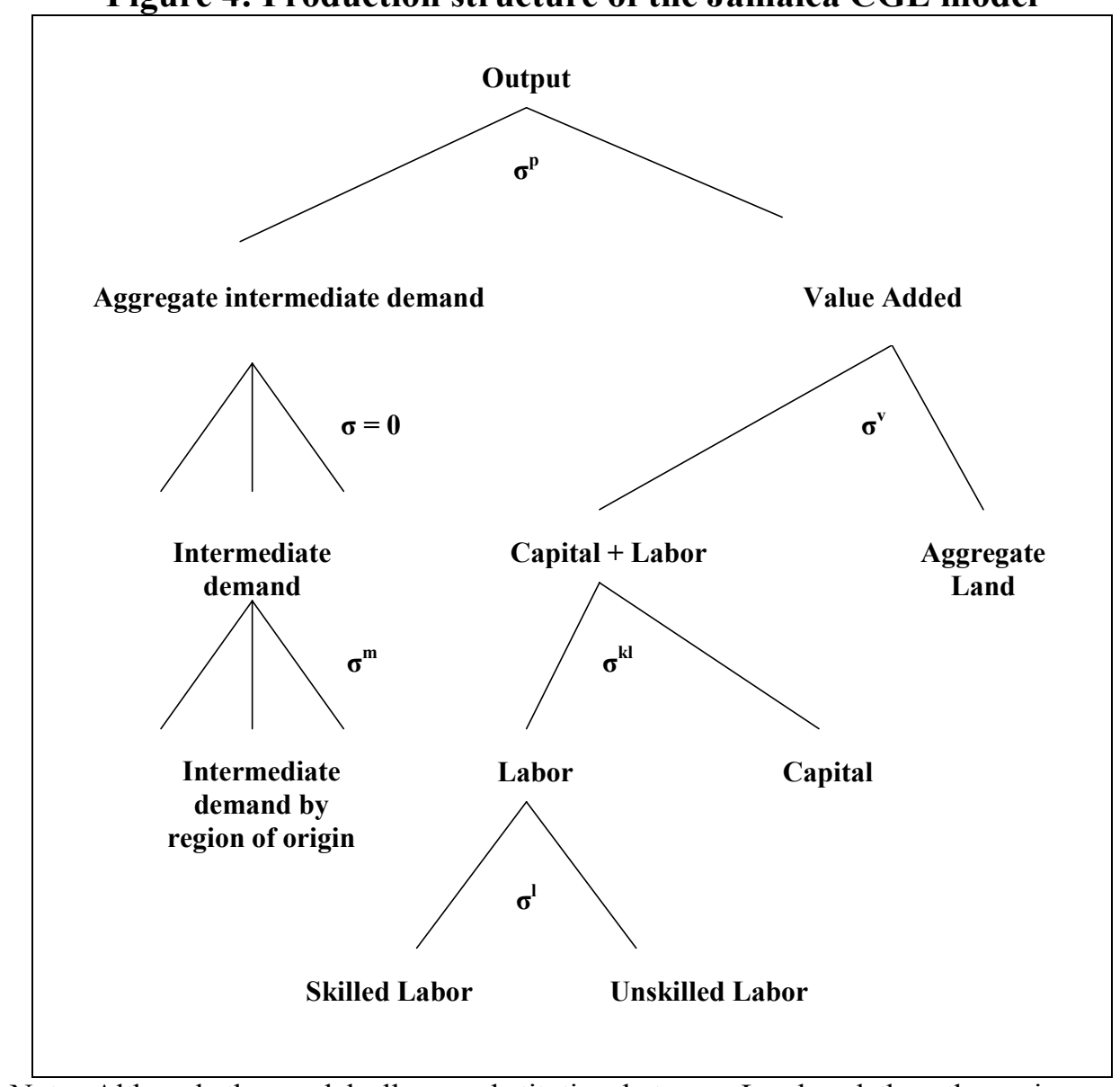

Note: Although the model allows substitution between Land and the other primary factors, given that the data for separating land and other factors contributions to value added was not available, the nesting structure actually active in the current model does not include Land as a separate factor.

In order to allow changes in remittance inflows to influence the household decision to supply labor, a consumption-leisure trade-off in the household utility function - similar to the approach of Barzel and McDonald (1973), de Melo and Tarr (1992), and Annabi (2003) - is introduced. Consider a Stone-Geary utility function and a budget constraint of the following form:

$$
u=\sum_{i=0}^{N} \mu_{i} \ln \left(C_{i}-\theta_{i}\right) \quad \text { s.t. } \sum_{i=0}^{N} P_{i} C_{i}=Y=W T+y
$$


In the utility function, $C_{i}$ denotes the consumption of good $i$ with leisure $\left(C_{0}\right)$ being a normal good, $\theta_{\mathrm{i}}$ are usually interpreted as consumption minima, ${ }^{20}$ and the share parameters $\mu_{\mathrm{i}}$ (including $\mu_{0}$ ) must sum to unity. $T$ denotes the total time a household has available for work and leisure activities, and the amount of resources available for non-leisure consumption is limited by nonlabor income $(y)$ and total wage income (ignoring saving and taxes for simplicity). ${ }^{21}$ Constrained maximization gives rise to the familiar linear expenditure system (LES ) demand functions:

$$
C_{i}=\theta_{i}+\frac{\mu_{i}}{P_{i}}\left(Y-\sum_{i=0}^{N} P_{i} \theta_{i}\right)
$$

The household labor supply is the difference between total time available and the time allocated to consumption of leisure, and substituting the budget constraint into the demand function yields:

$$
L S=\left(1-\mu_{0}\right)\left(T-\theta_{0}\right)-\frac{\mu_{0}}{W}\left(y-\sum_{i=1}^{N} P_{i} \theta_{i}\right)
$$

Partially differentiating the labor supply equation with respect to disposable income and the wage rate yields the following elasticities:

$$
\begin{aligned}
& \varepsilon_{y}=\frac{\partial L S}{\partial y} \frac{y}{L S}=-\frac{\mu_{0}}{W} \frac{y}{L S}<0 \\
& \varepsilon_{W}=\frac{\partial L S}{\partial W} \frac{W}{L S}=\frac{\mu_{0}}{W * L S}\left(y-\sum_{i=1}^{N} P_{i} \theta_{i}\right)
\end{aligned}
$$

While the labor supply is decreasing in non-labor income, the sign of the wage elasticity depends on the ratio of non-labor income to the total "committed" consumption expenditures. ${ }^{22}$

Model Closures. The equilibrium condition on the balance of payments is combined with other closure conditions so that the model can be solved. First, aggregate government expenditures are fixed at the base year value. Government surplus is exogenous and the household income tax schedule shifts in order to achieve this predetermined net government position. Second, aggregate investment is set equal to aggregate savings. The volume of available savings is determined by a fixed level of foreign saving, exogenous government saving, and households who save a fixed share of their post-tax income (i.e. the marginal propensity to save is fixed).

\footnotetext{
${ }^{20}$ Note that there is no theoretical requirement for any of the $\theta_{\mathrm{i}}$ to be positive.

${ }^{21}$ Note that the price of leisure is the economy-wide wage rate $W$ (i.e. $P_{0}=W$ ).

22 This sign ambiguity allows for a backward-bending labor supply curve.
} 